the staff of the Scottish Marine Station on board the Medusa; the trips having been made in April, June, August, September, and November. The observations were made at all depths of the sea, from the surface to 107 fathoms. The novelty and, in not a few cases, the unexpectedness of the results render it advisable to delay a full discussion till more observations have been made and the densities worked out. In the meantime a provisional report on the results of the April and June trips, by Dr. H. R. Mill, will be read with interest. Among the unexpected results was the discovery in June in Loch Fyne of a lenticular mass of water with temperature below $43^{\circ}$ floating between two warmer strata, the cold area being most definite at its upper surface and more diffused below. The greatest thickness of the mass of water colder than $43^{\circ}$ was 180 feet, off Inveraray. Its lower bounding plane ran along the bottom from the head of the loch to Dunderave; then where the water deepens it dipped down again at the same angle until off Inveraray, where it bent up again and met the upper bounding surface at Furnace, I 20 feet under the surface of the loch.

In a paper:by the secretary on the meteorology of Ben Nevis, it is shown from the three years' observations at the low-level station and the high-level observatory that the mean decrease of temperature with height is at the rate of $\mathrm{I}^{\circ} \mathbf{F}$. for every 270 feet of ascent, the lowest monthly rate being $I^{\circ}$ for every 284 feet in winter and the most rapid rate 247 feet in spring. A table of the barometric corrections for height for the different sea-level pressures and air temperatures that occur has also been prepared directly from the observations themselves. The importance of the results of these two inquiries rests on the fact that the Ben Nevis pair of stations alone supply, owing to their great difference in height, close proximity horizontally, and the positions of their thermometers, the physical data of observation which satisfy with sufficient closeness the requirements of these funda. mental problems of meteorology. The science has now passed that stage when Great St. Bernard with Geneva, Mount Washington with Portland and Burlington, Hochobir with a station in one of the neighbouring deep valleys, or brief continued observations with balloons or at different heights on the slopes of the Faulhorn, can be accepted as affording the data required for dealing seriously with these questions.

\section{REPORT ON THE BOTANICAL GARDEN, SAHARUNPUR}

$M R$. DUTHIE'S “Report on the Progress and Condition of the Government Botanical Gardens at Saharumpur and Mussoorie for the Year ending March 3I, I886," which has recently reached us, contains, besides the usual routine matter, inseparable from such Reports, on the state of the Garden itself, much that has a wider range of interest. As usual, the cultivation of new plants of economic value appears to have occupied a considerable amount of attention during the year. Where so many useful plants have been introduced and reported upon, it is not an easy matter to select one or two for an example of the work in which Mr. Duthie is engaged. The character of this work is now, however, pretty well known, though the following extracts will show that plants of very varied character and uses are yearly being experimented with in our Indian and colonial botanic gardens.

Under the head of New Zealand spinach, a quantity of the seed of this vegetable is reported to have been received and planted, germinating freely and yielding a continuous crop of leaves, which, when cooked, is said to much resemble in flavour that of English spinach. The plants, Mr. Duthie says, seed freely, and he has no doubt that it will readily acclimatise ; though, as he says, the introduction is not one of much importance, except for variety, as it comes into season at the same time as English kinds, and it can hardly compete with them in popular estimation. This so-called New Zealand spinach many of our readers will remember as Tetragonia extansa.

The Oca-quina (Ullucus tuberosus) is another food plant upon which experiments in cultivation have been made. It is a native of South America, and the tubers, which are about the size of a walnut, and similar in appearance to a potato, are eaten, when cooked, by the people. Its cultivation in this country as a substitute for the potato was at one time proposed and attempted. Mr. Duthie says that twenty-eight tubers were received by him from the Royal Gardens, Kew, four of which were sent to the Arnigardh Garden, and the remainder were planted at Saharunpur. Up to within a few weeks of the date of the Report, these latter plants had made good growth, but after the commencement of the hot weather they became sickly, so that it is evident it will not suit the plains of India, but may succeed very well in the climate of Arnigardh, where it was intended that the majority of the plants should be sent.

Of the Japanese varnish-tree (Rhus vernicifera) the seedlings are stated to be making rapid progress. The growth for the two years after germination did not average more than a foot, which, however, has been doubled since the commencement of the hot season, and there is now no reason to doubt that this useful tree will thrive in the climate of Saharunpur. Mr. Duthie further says a small plantation will be made next rainy season, and it will then be a question of time as to when the plants will be ready for tapping.

Mr. Duthie makes the following interesting report on the subject of spider silk, which had previously attracted some attention. He says :- "I arrived from British Garwhal just in time to superintend operations at the commencement. The men employed on this work were provided with small sticks about a foot long, and they were told to collect as many clean webs as possible during the day. There was not much to show at the end of the day, as the silk takes up very little space when wound round these sticks, and the weight is inappreciable. The total weight of webs coliected during the season did not exceed ro lbs., the bulk of which was despatched to Mr. Wardle, of Leek. The cost of collecting the above, and the carriage from Bhim Teel to Saharunpur, and from Saharunpur to Bombay, amounted to Rupees 33-7-0. At this rate the export of spider silk to England would, of course, never pay, but expenses might be reduced very considerably: for instance, this first consignment included the weight of the sticks round which the silk was wound. The silk is removable after immersion in hot water. During my stay at Indalpur, in the Sháhjahánpur district, I saw some fine clean webs of the same kind in a forest about eight miles to the north of Indalpur."

Judging from the remarks of Mr. Duthie, there seems but little chance of spider silk ever becoming an article of commercial value.

The Report includes some interesting notes on some official tours made by $\mathrm{Mr}$. Duthie during the year, and a valuable list of plants collected, the names of which have been verified at the Royal Gardens, Kew.

\section{SCIENTIFIC SERIALS}

Bulletin de l'Académie des Sciences de St. Pétersbourg, tome xxxi. No. 3.-Corrections and additions to the Syrian-German and Votyak-German dictionaries, published in 1880 , by F. J. Wiedemann. These emendations are based on the following recent works: "The Land and Language of the Syrians," by Lytkin ; the publications on the Votyak language issued by the Kazan Mission; "Votyak Tales and Proverbs," collected by Dr. Aminoff, and published in the works of the recently insti. tuted Finnish-Ugrian Society; Dr. Max Buch's ethnographical sketch of the Votyaks in the "Actæ Societatis Scient. Fennicæ," vol. xii. ; and MM. Koshurnikoff and Miropolsky's monographs on the Votyaks. - On the Ornis of the western spurs of the Pamir and Alai, by V. Bianchi-On "Claudii Galeni Pergameni Scripta minora," by L. Nauck.

Nyt Masazin for Naturvidenskaberne, vol. xxx. Nos. 3 and 4 , Christiania, 1886. - This number of the Norwegian New Fournal of Sciences contains :-Continuation of Herr Brögger's paper on the geological history of the Christiania Fjord. According to the writer, it may be assumed that the bed of the fjord has been raised by eruption to the surface of an older bed, which consists of depressed strata of the earth's crust, whose depression had been connected with active processes of dislocation, crumpling, and folding in the post-Silurian period. The evidences of erosion and eruption are considered at length, with special reference to the action of glaciers in the formation of the fjord. -Dr. Lang concludes in an exhaustive paper his contributions to the study of the eruptive rocks of the Silurian beds of Christiania, and thus completes an important chapter in the geological history of South Scandinavia. - Notice of Regalecus glesne ascanius, by Herr J. Grieg. This specimen, a female, with welldeveloped ovarium, is the fourteenth that has been taken off the Norwegian coasts since 1740.- Report of the various attempts made within the last four years to introduce new plants into Iceland, by Dr. Schierbeck. The results of these efforts to 
enlarge the meagre flora of the island are scarcely encouraging. Thus, although hopes are entertained that some kinds of maples may thrive in sheltered spots, conifers, from whose introduction great expectations were entertained, have not given promise of success, while poplars, oaks, apple and pear trees have without exception died. Common red-and black-currant bushes thrive so far as to set fruit, but this does not ripen except in the warmer summers. Potatoes, which would be invaluable to the islanders, have not yet been' successfully cultivated, but turnips, rhubarb plants, and several of the hardier cabbages, together with lettuce and chamomile, do well. The great question, whether cereals can be cultivated, as would appear to have been the case in the times of the Sagas, does not seem to admit of a satisfactory solution, and, according to the writer, the present regular supply of corn from the mother-country by means of rapid steamers, no longer makes the attempt necessary or desirable from an economic point of view. An interesting list of the various plants introduced, with the times of sprouting, budding, \&c., adds to the value of Herr Schierbeck's paper.

Revue a'Anthropologie, troisième série, tome ii., Paris.Recapitulation, by M. Topinard, of the Society's instructions for noting the colour of the eyes and hair in France, with facsimiles of the printed papers distributed to intending observers, and directions how they should be filled up.-On a quinary nomenclature for the naial index in the living subject, by Dr. Collignon. The writer, who considers a correct and systematically rdetermined nasal index as the most important anthropometric determination, not excepting even the cephalic index, proposes to divide the ordinarily accepted nasal groups into hyper-leptorhinian, leptorhinian, mesorhinian, platyrhinian, and hyper-platyrhinian, including under the platyrhinian section all the black races, under the mesorhinian the yellow races generally, and under the leptorhinian most of the white races. The paper gives a clear and concise description of the instruments in general use, and of those best adapted for making the required measurements, which he regards as of paramount value in determining racial characteristics. - Contributions to the sociology of the Australian races, by Elie Reclus. This paper, which is principally concerned with the system of clanships and cousinships existing among these p:oples, has comparatively little interest for English readers, who have long been familiar with the curious questions involved in the principles of inter-tribal relationship. Indeed, M. Reclus has drawn so largely from the writings of Brough-Smyth, Eyre, Howitt, Taplin, Morgan, McLennan, and other British writers, that this first part of his paper is a mere résumé of some of the more sensational details of information contained in their several works. - Anthropological observations in Guiana and Venezuela, by Dr. Ten Kate. These observations chiefly refer to the differences between the native Caribs, the so called "wood Negroes," and half-castes. The first of these present two distinct types, reminding the anthropologist of the Red Indians in some respects, and of the Mongolian races in others; the second are a specially vigorous black tribe, the descendants of runaway slaves domiciled in the forests of Surinam. Most of these men are of herculean strength and stature. Numerous anthropometric and other tables illustrate the paper.-On the depopulation of France, by M. de Lapouge. This subject, which has lately been attracting renewed attention through the appearance of the second edition of M. de Nadaillac's interesting pamphlet "On the Decline of the Birth-Rate in France," is considered by the author from an anthropological as well as a social and moral point of view. After drawing attention to the fact that while between 1770 and 1780 there were 380 births for every 10,000 of the population, this number has gradually fallen to 235 for the present decade, and is thus lower than that of Switzerland, which had been assumed to have the lox est birthrate in Europe, and less than half that of Russia. According to the writer, the population of France has reached a stationary point, its annual increase of 80,000 admitting of no comparison with the hundreds of thousands, ana even millions, annually added to the populations of Germany, Russia, the United States, and the British Empire, while, moreover, this slight increase is solely to be referred to the constantly increased immigration into France of foreigners, who now constitute one million of the populatior, and who predominate so largely at some points as to have reduced the French language to a secondary place in such districts. The writer discusses the various causes, such as the adoption of Malthusian principles, alcoholism, Catholicism, immorality, want of patriotism, self-interest, \&c., to which the present low birth-rate has been referred. And rejecting these as inadequate, he insists that the main source of the increasing depopulation in France is the gradual obliteration since the great revolution of the blond dolichocephalic type, to which he considers most of the distinguished Frenchmen of earlier times belonged, while the representatives of the brachycephalic races, who have never distinguished themselves in science, art, or letters, have been able to take the lead through superiority of numbers. By their cupidity, narrow range of interests, and indifference to the traditions of family and national glory, he holds them responsible for the anomalous condition of the country, in which an unprecedented accumulation of wealth and great prosperity are associated with physical degeneration and diminished births. In the re-introduction of the dolichocephalic element through immigration the author sees the surest means of effecting a substitution of national type and the best prospects of securing renewed vitality to the French race.

Rendiconti del Reale Istituto Lombardo, December 1886.Obituary notice of the late honorary member of the Institute, Signor Marco Minghetti, by the Editor. Reference is made more especially to the illustrious statesman's great merits as a political economist and art critic.-On the liquors employed in the artificial cultivation of Bacteria and other minute organisms, by E. L. Maggi. The various gelatinous, albuminous, and other solutions now in general use are described, with remarks on the best means of preparing and rendering them sterile.-On the geometry of linear spaces in a space of $n$ dimensions, by Prof. E. Bertini. The author's theorem for ordinary space of three dimensions-" A necessary and sufficient condition for three straight lines to exist in a plane is that all straight lines meeting two of them at arbitrary points shall also meet the third "-is here generalised for a linear space $S$ of any number $n$ dimensions. - Meteorological observations made at the Brera Observatory, Milan, during the months of October, November, and December, 1886.

Rivista Scientifico-Industriale, December 1886.-Determination of the weight of the mercury contained in a thermometer, by Dr. G. Gerosa. Clayden having recently determined the volume of the mercury contained in a thermometer (Proceedings of the Physical Society of London, vol. vii. p. 367, 1886), Dr. Gerosa here gives a determination of its weight, which he had already worked out in the Rendiconti of the R. Academia dei Lincei, vol. x., $188 \mathrm{r}$.- On the electric transmission of force, by Dr. Gerosa. The paper gives a critical appreciation of the work done by M. Marcel Deprez at Creil and by M. Fontaine in the Atelier Gramme. He considers the latter experiments the more successful of the two, M. Fontaine showing that with more economic means the same results may be realised as were cbtained in the experiments at Creil. - On the development of electricity in the condensation of aqueous vapour, by Dr. Franco Magrini. In reply to Prof. Costantino Rovelli the author again shows that there is no perceptible development of electricity during the condensation of the vapour of water. A description follows of M. A. Nodon's hygrometer, already reported in the Fournal de Physique for October 1886 .

\section{SOCIETIES AND ACADEMIES LONDON}

Royal Sociaty, January I3.- "Supplementary Note on Remains of Polacanthus foxii." "By J. W. Hulke, F.R.S.

In a paper published in the Phil. Trans. 188I the author described some remains of a large Dinosaur, remarkable chiefly for its dermal armour, discovered some fifteen years previously in Brixton Bay by the late Rev. W. Fox, and then in his collection. These have since become national property ; and the large shield, which, for facility of transport, had been broken up by its discoverer into innumerable small pieces, having been recently reconstructed in the workshop of the British Museum, the author now describes this singular armature, and also some parts of the pelvis formerly obscured by rock. The pieces, which, in their very fragmentary condition, had been thought scutes, are now seen to be parts of a continuous osseous shield which protected the rump and loins, having its anterior surface ornamented with closely-set tubercles, and in each lateral half four longitudinal rows of keeled eminences. The ischium has its long axis directed transversely to that of the trunk, and not roughly parallel to it as in the Iguanodonts. 